\title{
Freshwater control of onset and species composition of Greenland shelf spring bloom
}

\author{
Joanna J. Waniek*, N. P. Holliday, R. Davidson, L. Brown, S. A. Henson \\ Southampton Oceanography Centre, European Way/Empress Dock, Southampton SO14 3ZH, UK
}

\begin{abstract}
The relationship between physical properties of the water column and spatial patchiness of phytoplankton spring bloom development on the Greenland shelf edge and in the Irminger Sea was investigated using data collected during a spring cruise (April and May 2002). The observations confirm a strong relationship between the onset and stage of bloom development and the stratification induced by freshwater input to the surface layer in the shelf region. Interestingly, at the shelf, in the region influenced by melting of the seasonal ice-cover, the vertical distribution of chlorophyll a showed a subsurface maximum at ca. $25 \mathrm{~m}$ depth at several stations. Since nutrients were not exhausted at these stations, such a pattern does not conform to the general picture of a spring bloom. In contrast, in the open ocean part of the Irminger Sea pre-bloom conditions and a retarded development of the phytoplankton population were observed with low, more uniform distribution of chlorophyll $a$. The nitrate drawdown was estimated at between 16.5 and $270 \mu \mathrm{m} \mathrm{m}^{-2}$ (mean $108.6 \pm 82.2 \mu \mathrm{m}$ $\left.\mathrm{m}^{-2}\right)$ and the new primary production was estimated to be between 1.3 and $21.4 \mathrm{~g} \mathrm{C} \mathrm{m}^{-2}(8.6 \pm 6.5 \mathrm{~g}$ $\mathrm{C} \mathrm{m}^{-2}$ ), corresponding to $0.42 \mathrm{~g} \mathrm{C} \mathrm{m}^{-2} \mathrm{~d}^{-1}$. The phytoplankton community in the melting ice zone consisted of Phaeocystis sp., small flagellates $(<4 \mu \mathrm{m})$ and picoplankton, while diatoms were less abundant. Phaeocystis sp. contributed up to $15 \mathrm{~g} \mathrm{C} \mathrm{m}^{-2}$ to the carbon biomass $(70 \%$ of total carbon measured), whereas the contribution of diatoms and flagellates to carbon biomass was relatively low, with up to $1.2 \mathrm{~g} \mathrm{C} \mathrm{m}^{-2}(5.7 \%)$ and up to $2.5 \mathrm{~g} \mathrm{C} \mathrm{m}^{-2}(11.7 \%)$, respectively. On the shelf the bloom starts at the very beginning of stabilisation (elevated $\mathrm{N}^{2}$ values) which results solely from the release of meltwater. The locally restricted water stability leads to a patchy phytoplankton distribution in the Irminger Sea.
\end{abstract}

KEY WORDS: Hydrography · Brunt-Väisälä frequency · Stratification · Phytoplankton · Plankton blooms $\cdot$ North Atlantic $\cdot$ Irminger Sea $\cdot$ East Greenland shelf

\section{INTRODUCTION}

In many regions of the world oceans, phytoplankton bloom dynamics are dominated by the spring bloom, a period of rapid population growth that often begins as the water column becomes (thermally) stratified. These blooms vary in magnitude, timing, and duration both spatially and interannually, and are a characteristic feature of the open waters of the temperate North Atlantic (e.g. Heinrich 1962, Savidge et al. 1992, Harrison et al. 1993, Waniek 2003), as well as coastal and estuarine waters in temperate latitudes (Cloern 1996 and references therein).
Spatial inhomogeneities like frontal systems (Strass 1992, Moore \& Abbott 2002, Read et al. 2002), mesoscale features (Savidge et al. 1992, Garçon et al. 2001), coastal upwelling (e.g. Hutchings et al. 1995) and marginal ice zones (e.g. Lancelot et al. 1993) are characterised by elevated biomass and production of phytoplankton at the surface. Along the oceanic edges of continental shelves, relatively high phytoplankton stocks have often been observed, together with distinctive hydrographic fronts marking the surface boundary between low-salinity water over the shelf and saltier water over the slope (Le Fevre 1986). It is now established that the spatial heterogeneity in phytoplankton 
distribution is associated with many processes on time scales ranging from seconds to months and covering spatial scales from millimetres to many hundreds of kilometres (Dickey 1988, Garçon et al. 2001, Read et al. 2002, Martin 2003 and references therein).

In the northern hemisphere, the propagation of the spring bloom from south to north has been shown to be associated with surface warming as indicated by outcrops of the $12^{\circ} \mathrm{C}$ isotherm (Strass \& Woods 1988). However, according to satellite images of chlorophyll $a$ in the northern North Atlantic, the spring bloom of algae occurs earliest in March to the north and south of Iceland and subsequently develops throughout the region simultaneously but patchily, rather than by progressive poleward shoaling of the seasonal pycnocline as occurs further to the south in the North Atlantic. The discontinuity between the bloom in the Arctic sector of the Atlantic open ocean and that of the Atlantic further south is important but largely unrecognised. Campbell \& Aarup (1992) reported a very early bloom in the Arctic/Subarctic sector at 60 to $65^{\circ} \mathrm{N}$ of the Labrador Sea initiated at about the same time as the start of the bloom at about $35^{\circ} \mathrm{N}$ in the subtropical gyre.

The timing of the phytoplankton spring bloom is one of the crucial factors determining the length of the productive period, the annual primary production and how the phytoplankton blooming matches with the life cycle of grazers. Additionally, the phytoplankton bloom is one of the major determinants of the flow of carbon through the marine food web and may also influence the global climate by effecting the drawdown of $\mathrm{CO}_{2}$ from the atmosphere to the deep ocean (Sarmiento \& Toggweiler 1984, Smith et al. 1991, Falkowski et al. 2000), which is mediated via sedimentation of biogenic material (Deuser \& Ross 1980, Rice et al. 1986, Honjo 1996).

In the northern North Atlantic, blooms may be determined to an important extent by salinity-driven density stratification due to the freeze-melt cycle of sea ice and the modification of Atlantic water by lower salinity polar surface waters (Campbell \& Aarup 1992). Blooms initiated at the ice edge or in regions influenced by fresh water have been reported from other regions like the Bering Sea (e.g. Sukhanova et al. 1999 and references therein), the Norwegian Sea (Peinert 1986), the Iceland Basin (Thordardottir 1986) and the Greenland Sea (Smith et al. 1991). Various lines of evidence indicate that the marginal ice zone is a region of enhanced primary production owing to the formation of ice, the time of ice melting and the development of a shallow, vertically stable pycnocline (Thordardottir 1986, Lancelot et al. 1993, Strass \& Nöthig 1996).

The main aims of this paper are: (1) to present unique observations from the Greenland shelf in the Irminger Sea sector collected during the transition time from winter to spring in April/May 2002; (2) to emphasise the role of haline stratification for the timing of the phytoplankton bloom in this region; (3) to demonstrate that the heterogeneity of the chlorophyll a biomass and species composition are coherent with the differences in hydrographic conditions on the sub-mesoscale. Additionally, nitrate drawdown and the associated new primary production for the region is calculated and compared to early estimates for the polar regions. Finally, satellite measurements of surface chlorophyll a derived from SeaWiFS are used to place the field observations into a more general context and to assess the scale of interannual variability in this region.

\section{MATERIALS AND METHODS}

The physical factors controlling the zooplankton distribution in the Irminger Sea and Iceland Basin were investigated during 4 cruises as part of the 'Marine Productivity Programme', a UK contribution to international GLOBEC. Data from the spring cruise in April and May 2002 (Cruise D 262) were analysed, especially nutrients, chlorophyll $a$ and the vertical distributions of temperature and salinity measured using a Sea Bird 911 CTD (Fig. 1). The stations were occupied in the vicinity of melting pack ice and within the ice. Salinity data from the CTD were calibrated against discrete bottle samples to WOCE (World Ocean Circulation Experiment) standards $( \pm 0.002)$. The vertical profiles of Brunt-Väisälä frequency squared $\left(N^{2}=-g / \rho\right.$. $\mathrm{d} \rho / \mathrm{d} z$, where $\rho=$ density, $z=$ depth and $g=$ the acceleration due to gravity), were used to describe the water column stabilisation.

Discrete samples for nutrient and chlorophyll $a$ analysis were collected from Niskin bottles on the CTDrosette system. All nutrient samples were collected in new $40 \mathrm{ml}$ diluvials and refrigerated at $4^{\circ} \mathrm{C}$ until analysis. Analysis of all samples took place within $12 \mathrm{~h}$ of the time of sampling (Sanders \& Jickells 2000). Concentrations of the dissolved inorganic nutrients nitrate and nitrite (hereafter nitrate) and silicate were measured on unfiltered water samples using a Scalar SanPlus segmented flow-autoanalyser based on the analytical methods of Kirkwood (1995). Throughout each sample run, wash-and-drift standards were run every 10 to 15 min to enable baseline and drift corrections. Nutrient concentrations were calculated using calibration curves obtained from dilution of the in-house standards, analysis of OSI (Ocean Scientific International) nutrient standards, and measurement of a deep-ocean, bulk seawater standard. The precision of the nutrient measurements was estimated to be better than $\pm 0.18 \mu \mathrm{M}$ for nitrate and $\pm 0.15 \mu \mathrm{M}$ for silicate $(1 \%$ for standard nitrate and $0.5 \%$ for silicate). 


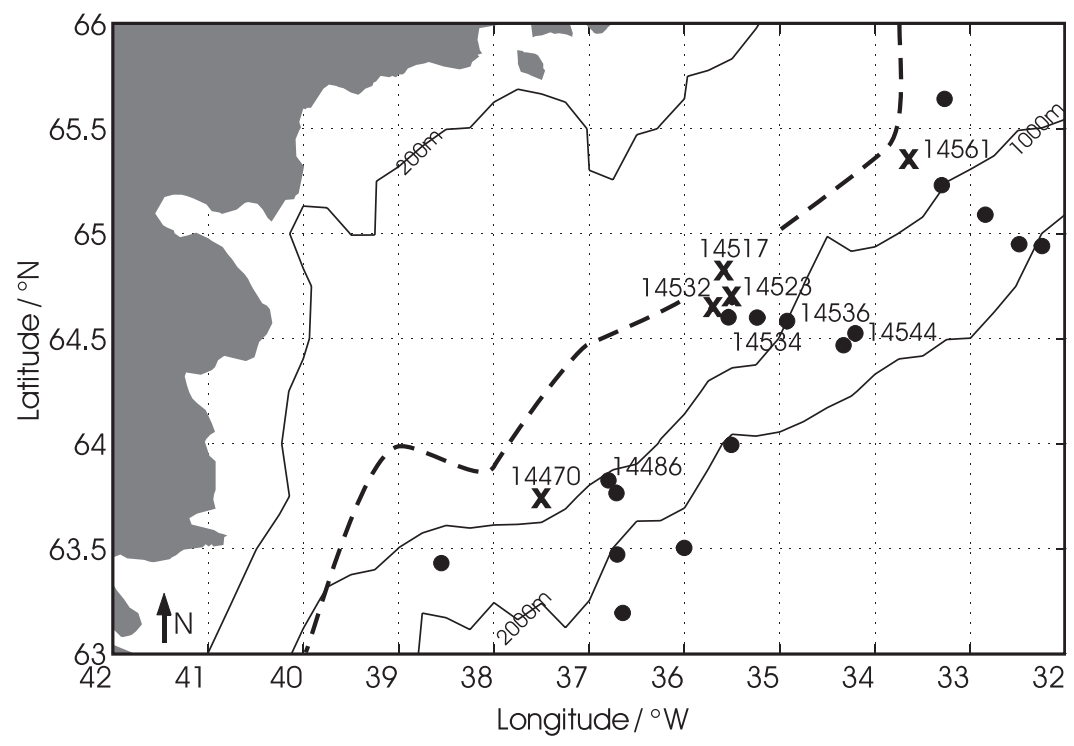

Fig. 1. Study area and location of CTD stations during spring cruise D 262 in April and May 2002, showing isobaths of 200, 1000 and $2000 \mathrm{~m}$. Stations used in this study are indicated by cast numbers. (X) stratified stations under influence of melting sea ice; $(\bullet)$ stations with low stratification outside ice-melt region; dashed line indicates ice-edge position on 10 May 2002, adapted from satellite image provided by Dartcom (Richards et al. 2002)

CTD fluorometer readings were converted to chlorophyll a concentrations by calibration against discrete bottle samples. Water samples were drawn into $5 \mathrm{l}$ carboys. For the chlorophyll analysis, two $200 \mathrm{ml}$ aliquots were filtered through Whatmann GF/F filters. The filters were placed in amber glass vials containing $90 \%$ acetone and stored in the dark for $24 \mathrm{~h}$ to extract chlorophyll a. Samples for chlorophyll a were warmed to room temperature before the fluorescence was measured using a Turner Design fluorometer (TD700). Chlorophyll standard solutions (Sigma) were used for calibration of the fluorometer prior to analysis of each set of samples. The chlorophyll concentrations were calculated from the absorbance measured at 750, 664, 647 and $630 \mathrm{~nm}$ in a Cecil spectrophotometer using the equations of Jeffrey \& Humprey (1975). Calibration of the CTD fluorometer was performed by calculating a linear fit between the bottle samples and CTD fluorometer readings. The CTD casts were split into on- and off-shelf sets for the calibration. The calibrations were as follow: chl $a=4.2506+0.0652 \times$ fluorometer value, with $\mathrm{r}^{2}=0.71, \sigma=0.33$ at the shelf and chl $a=-0.0022+3.9032 \times$ fluorometer value $\left(\mathrm{r}^{2}=0.92\right.$, $\sigma=0.21$ ) for the off-shelf stations. The standard deviation of the residuals after applying the calibration to the CTD fluorometer data was $0.2 \mathrm{mg} \mathrm{m}^{-3}$ (Fig. 2).

Phytoplankton samples were taken at the surface, at the chlorophyll maximum and at $100 \mathrm{~m}$ depth. Duplicates of $100 \mathrm{ml}$ samples at each depth were preserved with $1 \%$ Lugol's solution and $2 \%$ buffered formalin.
The enumeration of taxa was done by inverted microscopy. Counts for individual species were converted to volume measurements of cells (Kovala \& Larrance 1966) and then to cell carbon using the cell volume to carbon relationships given by Eppley et al. (1970) as described by Holligan et al. (1984). Picoplankton samples were enumerated with at LEICA DMIRB microscope with a 1000 times magnification.

\section{RESULTS}

\section{Vertical temperature, salinity and nutrient distributions}

The vertical distributions (0 to $100 \mathrm{~m}$ ) of temperature, salinity and nutrients (nitrate, silicate) differed between stations at the Greenland shelf and in the Irminger Sea (Figs. 1 \& 3). At Stns $14470,14517,14523$ and 14532, a surface layer $10 \mathrm{~m}$ thick, with low salinity (minimum 33.11) was observed, because of the combined effects of cold sea-ice meltwater and fresh water of Arctic origin transported southwards by the East Greenland Coastal Current (EGCC) and East Greenland Current (EGC) along the continental margin. Below the freshwater layer the salinity showed a gentle increase to a

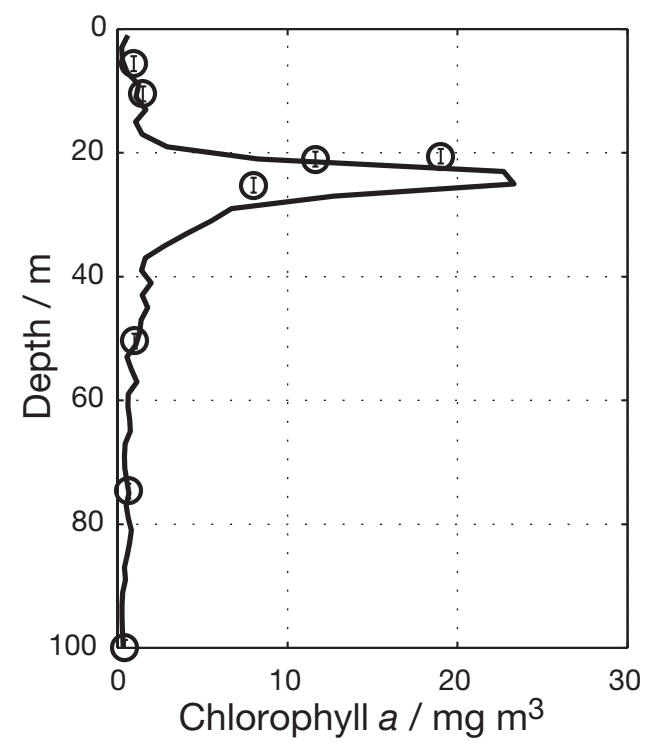

Fig. 2. Calibrated fluorescence profile (line) and discrete measurements of chlorophyll a (O) at Stn 14517, where standard deviation $\sigma=0.2 \mathrm{mg} \mathrm{m}^{-3}$ (inside data points) indicates difference between all calibrated profiles and discrete measurements 


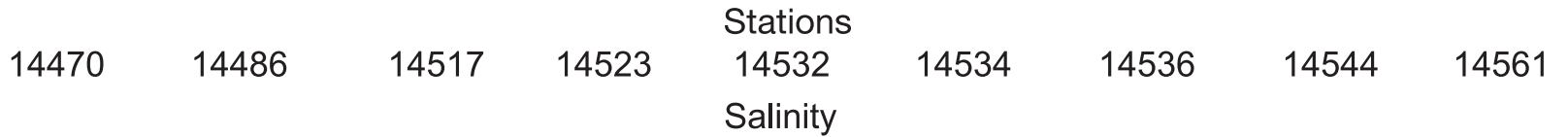

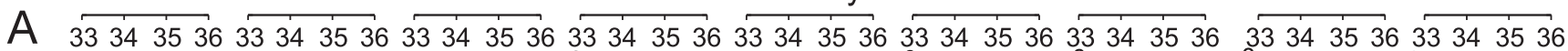
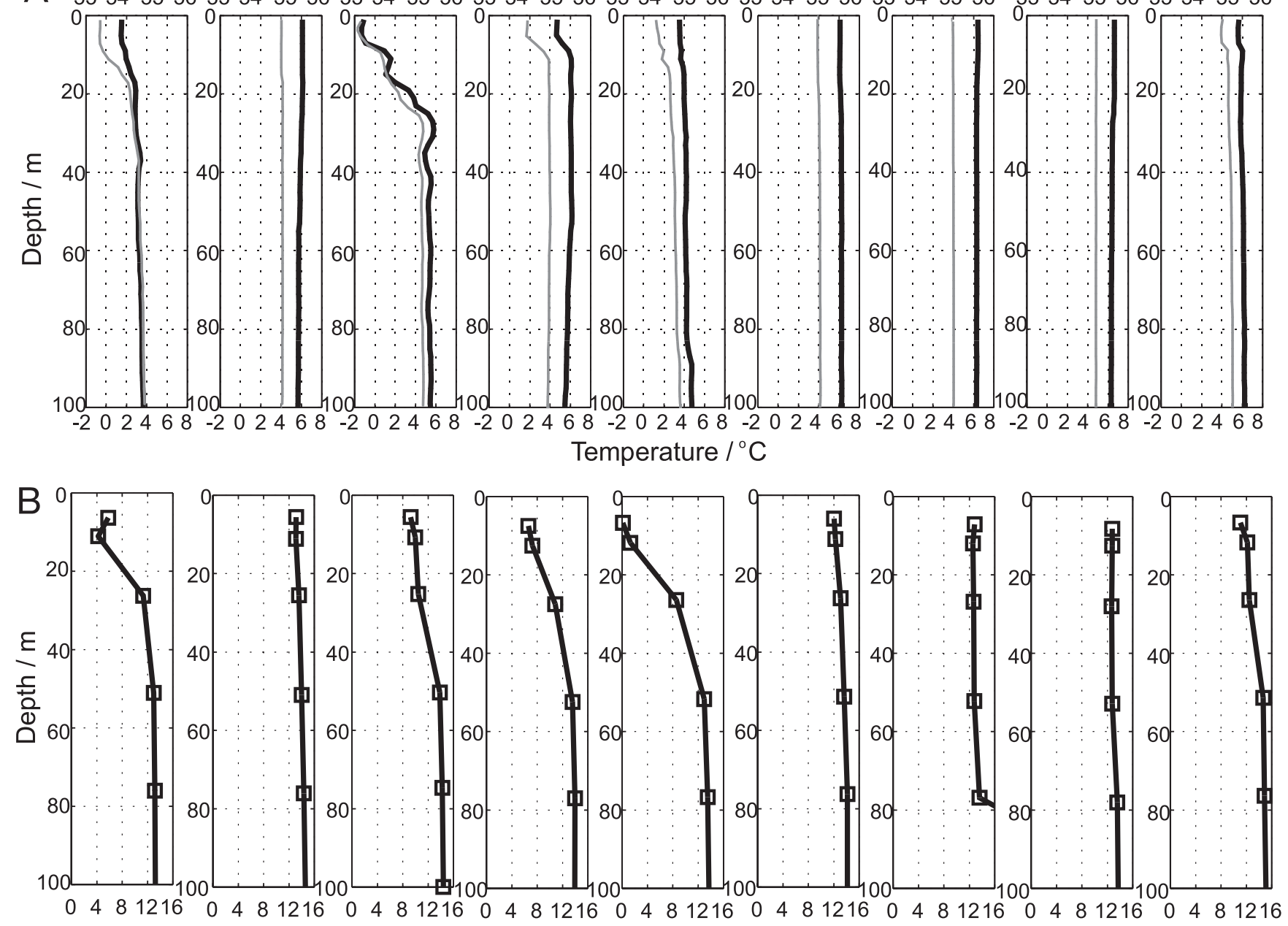
Nitrate / $\mu \mathrm{M}$

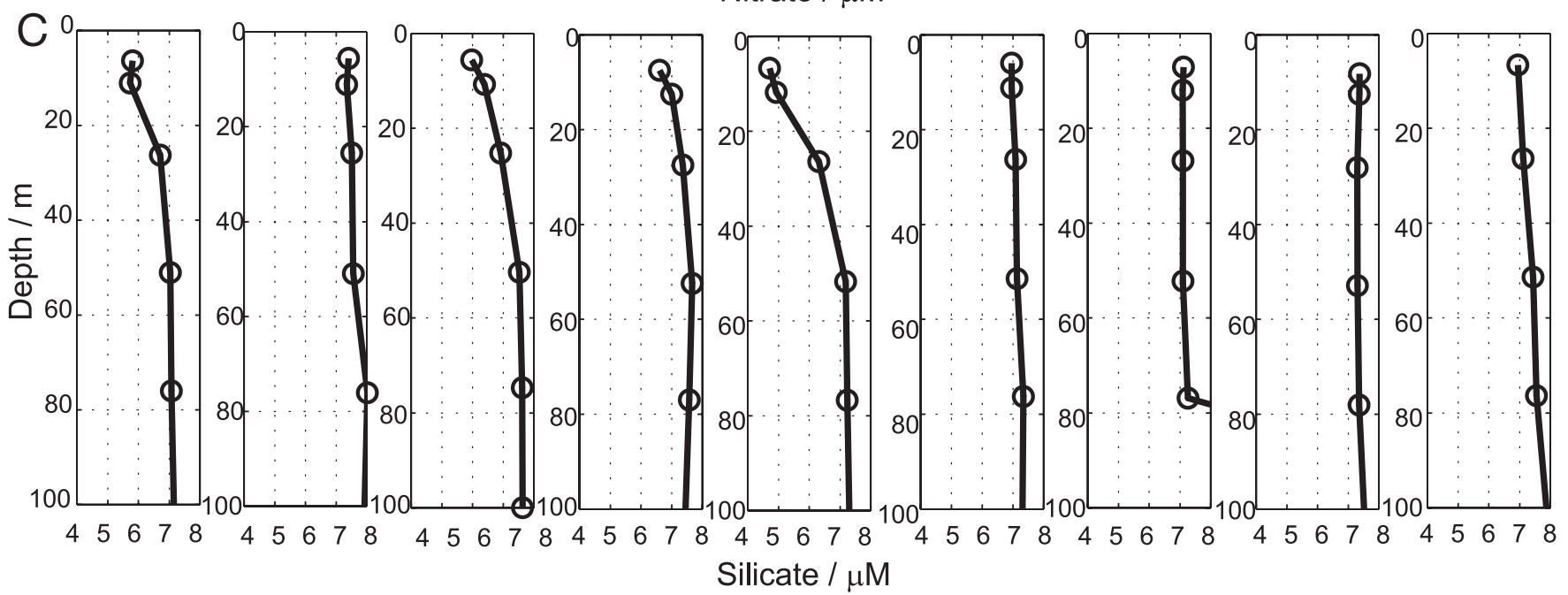

Fig. 3. Vertical profiles of (A) temperature (black line) and salinity (grey line), (B) nitrate and (C) silicate at selected stations. Station locations in Fig. 1 


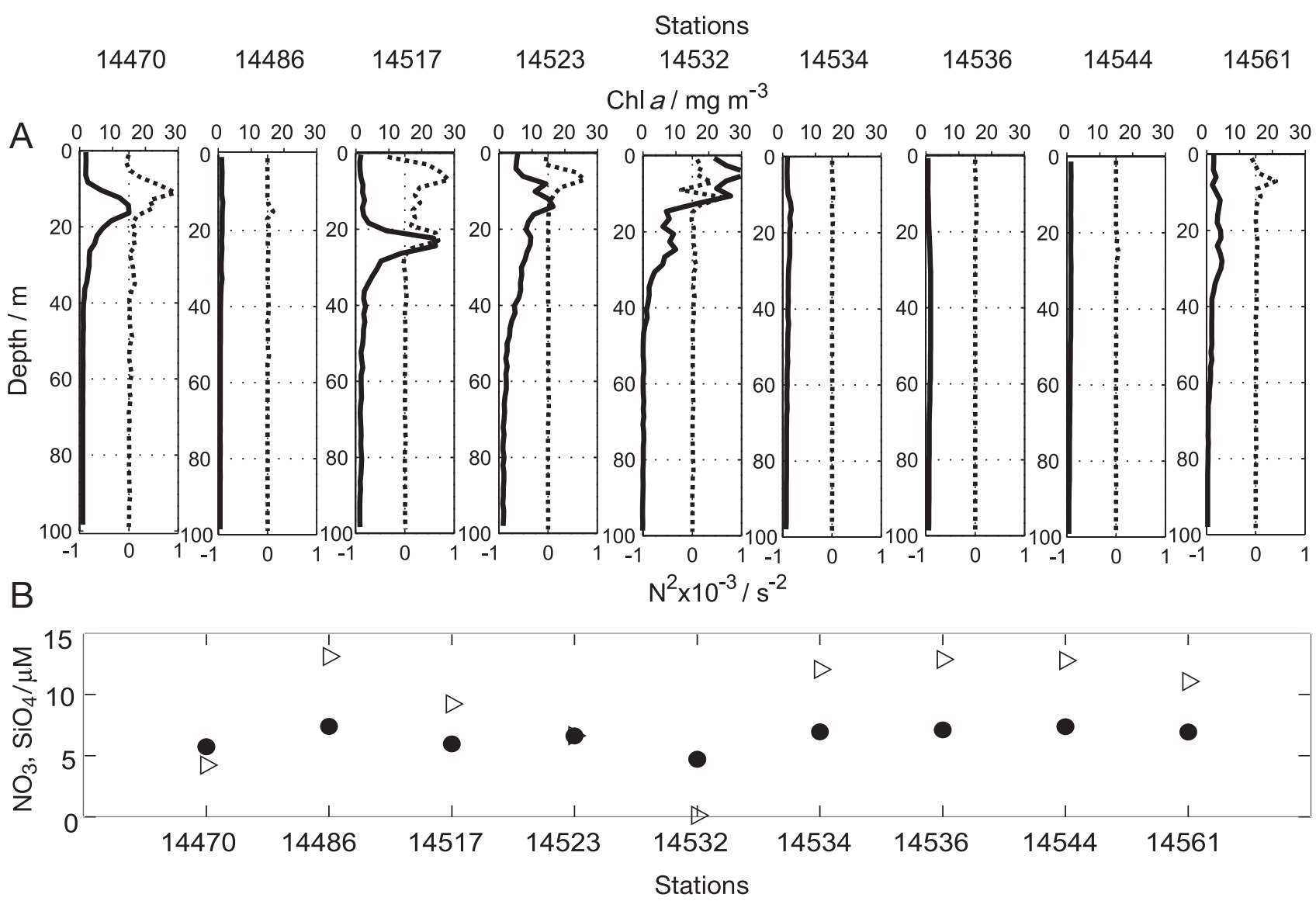

Fig. 4. Vertical profiles of (A) Brunt-Väisälä frequency squared $\left(N^{2}, \mathrm{~s}^{-2}\right.$, dotted line) and chlorophyll a (mg $\mathrm{m}^{-3}$, continuous line) and $(B)$ surface concentration of nitrate $(\triangleright)$ and silicate $(\bullet)$, at selected stations on Greenland shelf. Station locations in Fig. 1

salinity ${ }^{1}$ higher than 35 at ca. $40 \mathrm{~m}$ depth. The freshwater layer was characterised by low temperatures between -2.00 and $2.00^{\circ} \mathrm{C}$. At the other stations (14486, 14534, 14536 and 14544) a relatively deep mixed layer with uniform distribution of temperature $\left(6^{\circ} \mathrm{C}\right)$ and salinity higher than 34.75 was found, indicating water originating in the Atlantic. Overall, the temperature profiles showed less vertical structure than salinity at all stations except Stns 14470 and 14517. Lower concentrations of nitrate and silicate were found at Stns 14532, 14517, 14470, 14523 and 14561, where a fresh and coolwater layer was found near the surface (Fig. 3A). At Stn 14532, nitrate was nearly at the detection limit $(0.13 \mu \mathrm{m})$ and silicate reached $5 \mu \mathrm{m}$, but generally the nutrient concentrations were well above limiting values (Fisher et al. 1988). Surface nitrate and silicate concentrations were higher at Stns 14486, 14534, 14536 and 14544, with nitrate concentrations between 4.2 and $13.1 \mu \mathrm{m}$ and silicate ranging from 4.7 to $7.4 \mu \mathrm{m}$ (Figs. 3B,C \& 4B).

${ }^{1}$ Salinity (or practical salinity, PSS78) by definition does not have units. For explanation and more details see Siedler (1998)

\section{Water-column stability}

The hydrographic conditions in the water column indicated that some stations were characterised by a relatively deep mixed layer, but that others exhibited increased stratification in the upper $50 \mathrm{~m}$ with a fresh and cold, shallow pycnocline. Vertical profiles of the BruntVäisälä frequency squared $\left(N^{2}\right.$, for definition see 'Materials and methods') are a measure of the watercolumn stability. For the Barents Sea, Strass \& Nöthig (1996) reported a maximum of $N^{2}=0.1 \times 10^{-3} \mathrm{~s}^{-2}$ for a region where a shallow seasonal mixed layer was formed. The profiles show a pattern of elevated $N^{2}$ values, indicating strongly stratified waters on the coast and shelf-break, and vertical homogeneity in the openocean waters of the Irminger Sea (Fig. 4A). At all stations with elevated $N^{2}$ values, high chlorophyll a concentrations (up to $30 \mathrm{mg} \mathrm{m}^{-3}$ ) were observed. Chlorophyll a profiles had subsurface maxima below the depth of $N^{2}$ maxima (15 to $25 \mathrm{~m}$ ) at Stns 14470 , 14517 and 14523, whereas at Stn 14532 both the maximum chlorophyll a values and the high-stability region occurred in the same depth range. At the remaining stations a more uniform vertical distribution of chloro- 
phyll a with concentrations up to $4.8 \mathrm{mg} \mathrm{m}^{-3}$ was observed. In contrast, in the open Irminger Sea, high nutrient reserves, low chlorophyll a concentrations $\left(<1 \mathrm{mg} \mathrm{m}^{-3}\right.$ ) and weak stratification (low $N^{2}$ ) were found (Fig. 4). At the shelf-break, however, large variations in nutrient and chlorophyll a concentrations showed the presence of different developmental stages of the spring bloom coupled to the water stability (Fig. 4).

\section{Nitrate removal and new primary production}

The nitrate drawdown in the region was estimated as the difference between the observed nitrate concentrations at each depth and $14 \mu \mathrm{m}$ nitrate (a typical winter surface concentration in this region as suggested by Glover \& Brewer 1988) and then integrated over the top $100 \mathrm{~m}$ (Table 1). Maximum nitrate drawdown of $270 \mu \mathrm{m} \mathrm{m}^{-2}$ was estimated at Stn 14532, followed by Stn 14470 with $203 \mu \mathrm{m} \mathrm{m}^{-2}$. At the other stations nitrate removal values between 16.5 and $139.1 \mu \mathrm{m} \mathrm{m}^{-2}$ were calculated, with a mean value over the entire region of $108.6 \pm 82.2 \mu \mathrm{m} \mathrm{m}^{-2}$ (Table 1 ). The nitrate drawdown was converted into the new primary production in this region using the Redfield ratio (Redfield et al. 1963) for C:N of 6.6 (Table 1). The maximum new primary production of $21.4 \mathrm{~g} \mathrm{C} \mathrm{m}^{-2}$ was estimated for Stn 14532, which corresponds to $1.08 \mathrm{~g} \mathrm{C} \mathrm{m}^{-2} \mathrm{~d}^{-1}$ taking into account a $20 \mathrm{~d}$ period between the end of winter (midApril) and the measurements during the end of April and in early May. The average new primary produc- tion in this region was estimated to be $8.6 \pm 6.5 \mathrm{~g} \mathrm{C} \mathrm{m}^{-2}$ for the $20 \mathrm{~d}$ period, corresponding to a mean daily production of $0.42 \mathrm{~g} \mathrm{C} \mathrm{m}^{-2} \mathrm{~d}^{-1}$ (Table 1).

\section{Chlorophyll a biomass and species composition}

The maximum chlorophyll a biomass integrated over the upper $100 \mathrm{~m}$ was found at Stn 14532, with $528.3 \mathrm{mg}$ $\mathrm{m}^{-2}$. Stns 14561, 14470, 14517 and 14523 followed, with biomass levels ranging between 182.9 and $413.6 \mathrm{mg}$ $\mathrm{m}^{-2}$ (Table 1). The remaining stations were characterised by much lower chlorophyll a biomass levels (42.7 to $76.9 \mathrm{mg} \mathrm{m}^{-2}$ ). In order to compare the different sampling sites, the ratio between the depth-integrated new primary production (PP) calculated from nitrate drawdown and depth integrated chlorophyll a biomass $\left(\mathrm{B}_{\mathrm{chl}}\right.$ ) was considered (Allen 1971). This PP: $\mathrm{B}_{\mathrm{chl}}$ ratio depends on the species and on the assumption that the maximum potential rate of light-harvesting is a function of the chlorophyll a content of the cell, where the cellular chlorophyll content is controlled by the light received by the cell and nutrient availability. Therefore the $\mathrm{PP}: \mathrm{B}_{\mathrm{chl}}$ ratio indicates the efficiency of carbon fixation of the phytoplankton population, and the inverse of the ratio gives the amount of time it takes to replace the biomass of the population (Benke 1984). A high PP: $\mathrm{B}_{\mathrm{chl}}$ ratio indicates that the phytoplankton populations are not significantly limited by nutrients or other factors and the carbon fixation rate is close to optimum under the prevailing environmental conditions.

Table 1. Summary of environmental conditions and the biological characteristics investigated. For details of stratification see 'Results' and Fig. 4. Chlorophyll $a_{\mathrm{z}=0}$ : chlorophyll a measured at ocean surface; Int. chl a: chlorophyll a integrated over $100 \mathrm{~m}$ depth; Nitrate drawdown: calculated as deficit between winter nitrate concentration of $14 \mu \mathrm{M}$ (Glover \& Brewer 1988) and observed nitrate concentration during the cruise integrated from surface to $100 \mathrm{~m}$; New production: calculated using C:N ratio of 6.6; Daily production: primary production (PP) based on 20 d period from mid-April to early May; PP: $\mathrm{B}_{\text {chl }}$ : efficiency of carbon fixation; here $\mathrm{B}$ (biomass) $)_{\mathrm{chl}}$ a was recalculated as $\mathrm{mgC} \mathrm{d}^{-1}$ using chlorophyll a: $\mathrm{C}$ ratio of 1:50; Turnover rate: calculated as $1: \mathrm{PP}: \mathrm{B}_{\mathrm{chl} \text { ai }}$ Mean daily primary production: calculated over all stations

\begin{tabular}{|c|c|c|c|c|c|c|c|c|c|}
\hline \multirow{2}{*}{ Parameter } & \multicolumn{4}{|l|}{ 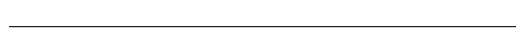 } & - Station & \multirow[b]{2}{*}{14534} & \multirow[b]{2}{*}{14536} & \multirow[b]{2}{*}{14544} & \multirow[b]{2}{*}{14561} \\
\hline & 14470 & 14486 & 14517 & 14523 & 14532 & & & & \\
\hline Surface salinity & 33.43 & 34.99 & 33.11 & 34.36 & 34.19 & 34.98 & 35.03 & 35.07 & 34.75 \\
\hline Stratification & strong & no & strong & strong & strong & no & no & no & weak \\
\hline Surface nitrate $(\mu \mathrm{m})$ & 5.83 & 13.12 & 9.23 & 6.63 & 0.13 & 12.06 & 12.86 & 12.78 & 11.06 \\
\hline Chlorophyll $a_{\mathrm{z}=0}\left(\mathrm{mg} \mathrm{m}^{-3}\right)$ & 1.14 & 0.64 & 0.61 & 5.04 & 21.99 & 0.72 & 0.3 & 0.94 & 2.26 \\
\hline Max. chl $a\left(\mathrm{mg} \mathrm{m}^{-3}\right)$ & 14.26 & 1.01 & 23.3 & 15.87 & 32.86 & 1.89 & 1.12 & 0.94 & 4.82 \\
\hline Depth of chl a max. (m) & 17 & 13 & 25 & 15 & 5 & 15 & 33 & 29 & 29 \\
\hline Int. chl a $\left(\mathrm{mg} \mathrm{m}^{-2}\right)$ & 189.5 & 42.7 & 245.3 & 413.6 & 528.3 & 76.9 & 73.5 & 70.6 & 182.9 \\
\hline Nitrate drawdown $\left(\mu \mathrm{mol} \mathrm{m}{ }^{-2}\right)$ & 203.0 & 16.5 & 99.3 & 139.1 & 270.0 & 42.7 & 74.7 & 81.8 & 50.0 \\
\hline New production $\left(\mathrm{g} \mathrm{C} \mathrm{m}^{-2}\right)$ & 16.1 & 1.3 & 7.9 & 11.0 & 21.4 & 3.4 & 5.9 & 6.5 & 4.0 \\
\hline Daily production $\left(\mathrm{g} \mathrm{C} \mathrm{m}^{-2} \mathrm{~d}^{-1}\right)$ & 0.8 & 0.06 & 0.4 & 0.54 & 1.08 & 0.16 & 0.30 & 0.32 & 0.2 \\
\hline $\mathrm{PP}: \mathrm{B}_{\mathrm{chl} \text { a }}$ ratio $\left(\mathrm{d}^{-1}\right)$ & 1.7 & 0.6 & 0.6 & 0.5 & 0.8 & 0.9 & 1.6 & 1.9 & 0.4 \\
\hline Turnover rate $(\mathrm{d})$ & 0.6 & 1.7 & 1.7 & 2.0 & 1.3 & 1.1 & 0.6 & 0.5 & 2.3 \\
\hline Mean daily production & \multicolumn{9}{|c|}{$0.42 \mathrm{~g} \mathrm{C} \mathrm{m}^{-2} \mathrm{~d}^{-1}$} \\
\hline
\end{tabular}


At Stn 14532, where high chlorophyll a concentrations were found near the surface and nitrate was near depletion, an efficiency ratio PP: $\mathrm{B}_{\mathrm{chla}}$ of $0.8 \mathrm{~d}^{-1}$ was found, corresponding to a turnover rate of $1.3 \mathrm{~d}$. Stn 14470 had a PP:B $B_{\text {chla }}$ ratio of $1.7 \mathrm{~d}^{-1}$ and a higher turnover rate of $0.6 \mathrm{~d}$. Efficiency ratios and turnover rates in a similar range were also found at Stns 14536 and 14544, where lower chlorophyll a concentrations and stronger mixing occurred (low $N^{2}$ ). Nutrients were not depleted here either, suggesting a phytoplankton community well-adapted to the prevailing conditions (mixing regime and light climate). Low $\mathrm{PP}: \mathrm{B}_{\mathrm{chla}}$ ratios were found at the stratified stations (14523 and 14517), where a subsurface maximum was observed. Here the turnover rates were 1.7 and $2.0 \mathrm{~d}$, respectively (Table 1). At the stations (14486 and 14534) without stratification in the upper $50 \mathrm{~m}, \mathrm{PP}: \mathrm{B}_{\text {chla }}$ ratios of 0.6 and $0.9 \mathrm{~d}^{-1}$ were found, implying turnover rates of 1.7 and $1.1 \mathrm{~d}$, respectively. At Stn 14561, where a weak stratification was observed, an efficiency ratio of $0.4 \mathrm{~d}^{-1}$ and a turnover rate of $2.3 \mathrm{~d}$ were estimated.

The high phytoplankton biomass on the Greenland shelf edge was due to the presence of small flagellates (2 to $4 \mu \mathrm{m}$ ), picoplankton, Phaeocystis sp. (with a few colonies) and some diatoms like Chaetoceros sp., Nitzchia delicatissima or Thalassiosira gravida. The average numbers of phytoplankton cells in the upper $100 \mathrm{~m}$ of the water column for the most abundant phytoplankton species are listed in Table 2. Of the diatoms, $N$. delicatissima was most abundant at all stations except 14544 and $14561\left(1.4 \times 10^{4}\right.$ to $1.4 \times$ $10^{6}$ cells $^{-1}$ ). T. gravida (1.4 to $9.2 \times 10^{4}$ cells l $^{-1}$ ) was the second most frequent diatom (Stns 14470, 14517, 14523 and 14536), followed by Chaetoceros sp. with $\left(1.7\right.$ to $5.8 \cdot 10^{4}$ cells $\left.^{-1}\right)$. Picoplankton and small flagellates $(2$ to $4 \mu \mathrm{m})$ were represented at all stations at all 3 depths levels. Picoplankton varied between 0.16 and $5.7 \times 10^{7}$ cells l$^{-1}$ and flagellates between 0.7 and $1.3 \times$ $10^{7}$ cells $\mathrm{l}^{-1}$. However, at $100 \mathrm{~m}$ depth, slightly lower numbers of flagellates and picoplankton were found (Fig. 5A). High numbers of single cells of Phaeocystis sp. and some small numbers of colonies were found in the top 2 layers along the transect at Stns 14532, 14523, 14517 and 14470. Phaeocystis sp. was most abundant at Stn $14532\left(5.7 \times 10^{7}\right.$ cells l$\left.^{-1}\right)$ at $5 \mathrm{~m}$ depth. Neither single cells of Phaeocystis sp. nor colonies were present at Stns 14544 and 14536 (Fig. 5A, Table 2). Along the transect, Phaeocystis sp. contributed most to the carbon biomass (up to $15 \mathrm{~g} \mathrm{C} \mathrm{m}^{-2}$ ), whereas the contribution of diatoms and flagellates to carbon biomass was relatively low, with up to $1.2 \mathrm{~g}$ and $2.5 \mathrm{~g} \mathrm{C} \mathrm{m}^{-2}$, respectively (Fig. 5B). Overall, Phaeocystis sp. contributed

Table 2. Species composition. Average number of phytoplankton cells in upper $100 \mathrm{~m}$ (1000 cells $\left.\mathrm{l}^{-1}\right)$ for the most abundant phytoplankton species

\begin{tabular}{|c|c|c|c|c|c|c|c|c|c|}
\hline \multirow{2}{*}{ Species } & $\longrightarrow$ & \multicolumn{3}{|c|}{ 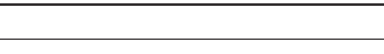 } & - Station & & \multirow[b]{2}{*}{14536} & \multirow[b]{2}{*}{14544} & \multirow[b]{2}{*}{14561} \\
\hline & 14470 & 14486 & 14517 & 14523 & 14532 & 14534 & & & \\
\hline \multicolumn{10}{|l|}{ Diatoms } \\
\hline Chaetoceros sp. & 1 & 0.1 & 4.1 & 12 & 3.8 & 0.02 & 0.02 & 0.04 & 0.18 \\
\hline Nitzchia delicatissima & 6.4 & 5.2 & 3.2 & 516 & 220 & 5.4 & 4.8 & 2.9 & 9.8 \\
\hline Thallassiosira gravida & 0.95 & 0.08 & 15 & 3.1 & 8.6 & 0.04 & & & 0.98 \\
\hline Others & 0.54 & 0.24 & 2.4 & 1.7 & 2.9 & 0.53 & 0.38 & 0.32 & 1.0 \\
\hline Total & 8.9 & 5.6 & 34 & 18 & 22 & 6 & 5.2 & 3.3 & 12 \\
\hline \multicolumn{10}{|l|}{ Phototrophic dinoflagellates } \\
\hline Gymnodimium sp. & 0.24 & 0.38 & 2.2 & 0.5 & 0.64 & 0.75 & 0.73 & 0.82 & 0.54 \\
\hline Others $(20 \mu \mathrm{m})$ & 0.22 & 0.18 & 1.8 & 0.47 & 0.34 & 0.61 & 1.1 & 0.98 & 1.3 \\
\hline Total & 0.46 & 0.56 & 4 & 0.97 & 0.98 & 1.36 & 1.8 & 1.8 & 1.84 \\
\hline \multicolumn{10}{|c|}{ Heterotrophic dinoflagellates } \\
\hline Gymnodinium sp. $\mathrm{H}$ & 5.6 & 0.55 & 1.8 & 1.1 & 1.1 & 2.6 & 2.9 & 3.0 & 1.7 \\
\hline Gyrodimium sf. fusiformis & 0.02 & 0.03 & 0.02 & 0.45 & 0.005 & 0.18 & 0.1 & 0.16 & 0.52 \\
\hline Others & 0.06 & 0.7 & 0.7 & 0.17 & 0.11 & 0.24 & 0.39 & 0.21 & 0.28 \\
\hline Total & 5.74 & 1.28 & 2.52 & 1.72 & 1.22 & 3.02 & 3.39 & 3.37 & 3.05 \\
\hline \multicolumn{10}{|l|}{ Flagellates } \\
\hline Cryptomonad & 6.3 & 43 & 420 & 710 & 47 & 29 & 100 & 110 & 48 \\
\hline Flagellates $(<2 \mu \mathrm{m})$ & 1100 & 2200 & 670 & 4800 & 2500 & 3600 & 3800 & 3900 & 2200 \\
\hline Flagellates $(<4 \mu \mathrm{m})$ & 21 & 54 & 180 & 130 & 59 & 180 & 200 & 180 & 40 \\
\hline Total & 1100 & 2300 & 6800 & 5000 & 2600 & 3800 & 4100 & 4200 & 2300 \\
\hline Phaeocystis sp. + colonies & 130 & 25 & 240 & 4600 & 840 & 15 & - & - & 250 \\
\hline Picoplankton & 6300 & 7600 & 22000 & 16000 & 6000 & 8600 & 11000 & 23000 & 3800 \\
\hline Coccolithophores & 0.17 & 0.91 & 0.46 & 1 & 0.62 & 2 & 3.4 & 3.2 & 1.3 \\
\hline Ciliates & 0.41 & 0.55 & 2.5 & 0.7 & 0.84 & 1.8 & 0.61 & 0.59 & 1.3 \\
\hline
\end{tabular}



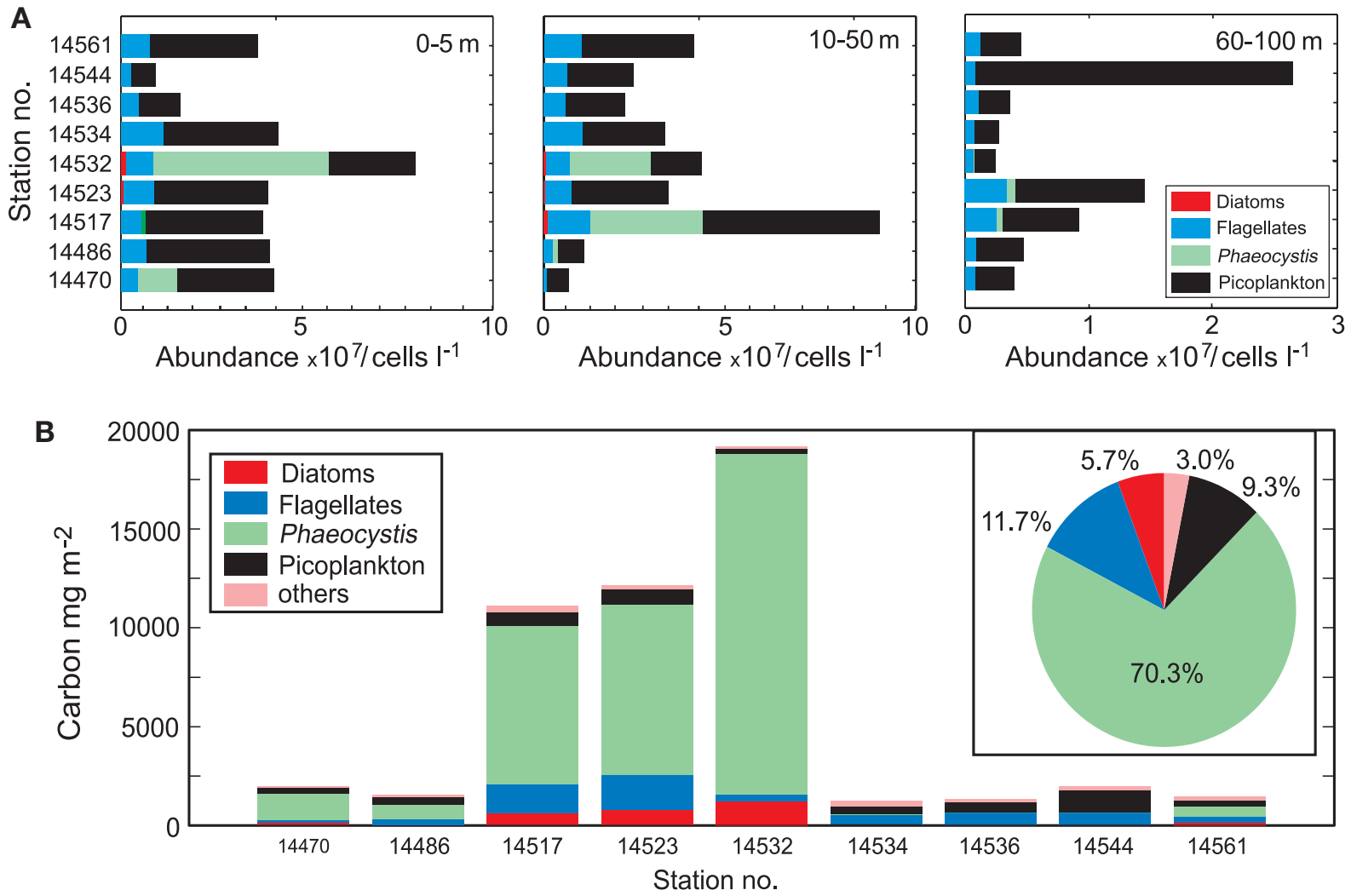

Fig. 5. (A) Abundance of diatoms, flagellates (2 to $4 \mu \mathrm{m})$, Phaeocystis sp. and colonies and picoplankton at 3 depth levels (cells $1^{-1}$ ); (B) carbon content of main spring phytoplankton groups on Greenland shelf integrated over top $100 \mathrm{~m}$; inset shows contribution of each main group to total carbon measured in this region; 'others' includes ciliates, coccolithophorid, heterotrophic and phototrophic dinoflagellates. Station positions in Fig. 1

$70 \%$ of the total carbon measured (integrated over $100 \mathrm{~m})$, followed by flagellates $(11.7 \%)$, picoplankton $(9.7 \%)$ and diatoms $(5.7 \%)$.

\section{DISCUSSION}

On the Greenland shelf, the spatial distribution of chlorophyll a concentration exhibited a close relationship with the $N^{2}$ distribution (Fig. 4). High phytoplankton biomass was observed in the region, where according to Bacon et al. (2002) fresh water and meltwater is transported southwards by the East Greenland Coastal Current and East Greenland Current along the coast. Here the highest phytoplankton biomass coincided with the highest water-column stability (high $N^{2}$ ) because of the shallow pycnocline. The phytoplankton community was typical for blooms in high latitudes, with Phaeocystis sp., small flagellates $(<4 \mu \mathrm{m})$ and picoplankton (Rat'kowa \& Wassmann 2002), while diatoms were less abundant. Outside the high-stability region, pre-bloom conditions were observed and the phytoplankton community consisted almost exclusively of flagellates, dinoflagellates, picoplankton and diatoms.

\section{Vertical chlorophyll a distribution}

Interestingly, the haline stratification has an effect on the stability of the water column very early in the year in these latitudes. At some stations, the chlorophyll a had a subsurface maximum at ca. $25 \mathrm{~m}$ depth (Stns 14470, 14517 and 14523). Strass \& Woods (1988) showed along a transect from the Azores $\left(38^{\circ} \mathrm{N}\right)$ into the cyclonic sub-Arctic gyre at $54^{\circ} \mathrm{N}$, that a chlorophyll a maximum descends approximately $10 \mathrm{~m}$ per month, leading to the conclusion that this bloom may have existed already for several weeks. Nutrient levels did not support this conclusion, since they were not exhausted at these stations. Therefore, such pattern does not conform to the general picture of a spring bloom, where typically deep chlorophyll maxima occur during the summer situations after nutrient exhaustion, or in nutrient-depleted waters in tropical regions.

The causes for such an early presence of a subsurface chlorophyll a maximum can only be speculated. It has been recognised that CTD fluorescence measurements can underestimate the true fluorescence under high irradiation at the sea surface due to photophysiological reduction of the fluorescence signal. However, the 
good correspondence between discrete chlorophyll a samples and the calibrated CTD fluorescence data precludes this possibility (Fig. 2). It is possible that water with high chlorophyll a concentrations had been subducted and/or advected into the region leading to the observed patchy phytoplankton development. However, chlorophyll a concentrations up to $30 \mathrm{mg} \mathrm{m}^{-3}$ were not observed at the surface anywhere in this region during the cruise, making this scenario rather unlikely.

Several other biological and physical explanations have been suggested in the past for the formation of a subsurface chlorophyll maximum. One hypothesis is that an increase in biomass begins near the surface and subsequently sinks, and is observed as a subsurface maximum. A second hypothesis argues that the gradual decrease in turbulent mixing throughout the pycnocline coupled with the decline of light intensity slows down the exchange between the well-mixed surface layer and the layers below, and allows the growth and decay of the phytoplankton in the various layers to proceed relatively independently of one another. As the light decreases, the time for phytoplankton to grow, utilise nutrients and decay increases. Bienfang et al. (1983), demonstrated that when a phytoplankton population characterised by the abundance of largecelled organisms in a shallow mixed layer with a well developed pycnocline experience changing light conditions, a reduction in sinking rates is the prime factor in the formation of the subsurface maximum. A final hypothesis is that grazing pressure by zooplankton is the major biological factor controlling phytoplankton development along a receding ice-edge (Smetacek et al. 1990). Castelani (2002) reported low numbers $\left(<1000\right.$ ind. $\left.\mathrm{m}^{-3}\right)$ of Oithona spp. at Stns 14517 and 14432, whereas higher numbers were typical at the remaining stations, with a maximum of 2800 ind. $\mathrm{m}^{-3}$ at Stn 14536. In contrast, relatively high numbers of Calanus spp. nauplii (400 to 1000 ind $\mathrm{m}^{-3}$ ) were found at Stns 14517 and 14432 and low numbers (200 ind. $\mathrm{m}^{-3}$ ) at the stations in the open Irminger Sea. This coherence between the slightly higher numbers of nauplii individuals at the stations with increased chlorophyll $a$ biomass may suggest a certain degree of grazing pressure. Irigoien et al. (2003) reported that the feeding efficiency of $C$. finmarchicus nauplii was highest on large cells (diatoms and ciliates); small flagellates were ingested with lower rates and Phaeocystis sp. was not ingested at all. However, an alternative hypothesis based on preferential feeding of Oithona spp. on microzooplankton (e.g. ciliates) and of Calanus spp. nauplii on ciliates and diatoms, and avoiding the Phaeocystis sp. is possible (Irigoien et al. 1998, 2000). In this situation, the mesozooplankton is actually removing the predators of small flagellates and picoplankton and diatoms, the possible competitors of Phaeocystis sp.
There is no reason to believe that a shortage in nutrients might have caused the differences in the phytoplankton species composition in early spring in the region. Data from the open Irminger Sea and even from the Greenland shelf (in April and May) show that the concentrations were still relatively high and well above limitation levels, indicating that little biological removal had occurred (Figs. $3 \& 4$ ). Although silicate and nitrate concentrations were high, the Phaeocystis sp. bloom coincided with that of small flagellates, picoplankton and diatoms. The Phaeocystis sp. dominated the population found between the surface and $50 \mathrm{~m}$, probably because of its high buoyancy. Phaeocystis sp. is especially favoured by the increased stability of the water column in the shelf region, and is able to out-compete the diatoms and flagellates in competition for light and nutrients (Serret et al. 2001). Tungaraza et al. (2003) reported for a Phaeocystis sp. dominated spring bloom in the North Sea that Phaeocystis had the ability to increase its ammonium uptake capacity when more ammonium became available. In contrast, diatoms failed to do so, after ammonium had exceeded their saturation concentration of $>1 \mu \mathrm{M}$. Although reduced nitrogen has a negative effect on the uptake of nitrate, Phaeocystis sp. has more advantage than diatoms in the uptake of ammonium. Additionally, a light threshold of $100 \mathrm{~W} \mathrm{~m}^{-2} \mathrm{~d}^{-1}$ was found to trigger the rapid growth of Phaeocystis sp. (Peperzak et al. 1998). The strong presence of flagellates in the upper $50 \mathrm{~m}$ reflects their ability to use their locomotory powers to position themselves at a depth of optimum nutrient and illumination levels. The abundance of diatoms was surprisingly low, especially at the stratified stations (high $N^{2}$ ), most probably because they flourish best under turbulent conditions that bring them back to the surface from time to time (Margalef 1978, Holligan et al. 1984, Cushing 1989, Huisman et al. 1999).

Overall, in this study, the subsurface chlorophyll maximum at the stations influenced by the melting of the seasonal ice-cover, is probably the result of the combined effect of the adaptation of different phytoplankton species to different environmental conditions, e.g. mixing regimes and subsequently different light climate, with some influence by zooplankton. This conclusion is also supported by the calculated efficiency ratio of carbon fixation and the turnover rates (Table 1).

\section{New primary production}

In this study, an averaged new daily production for this region of $0.42 \mathrm{~g} \mathrm{C} \mathrm{m}^{-2} \mathrm{~d}^{-1}$ was estimated, which would lead to an annual primary production of $76 \mathrm{~g} \mathrm{C} \mathrm{m}^{-2} \mathrm{yr}^{-1}$ 
assuming a productive period of 6 months. This annual new production is slightly higher than the annual new production calculated by Henson et al. (2003) of $60 \mathrm{gC}$ $\mathrm{m}^{-2} \mathrm{yr}^{-1}$ from the temperature-nitrate relationship and by Sanders \& Brown (in press) of $50 \mathrm{~g} \mathrm{C} \mathrm{m}^{-2} \mathrm{yr}^{-1}$ based on in situ measurements, but somewhat lower than the $100 \mathrm{~g} \mathrm{C} \mathrm{m}^{-2} \mathrm{yr}^{-1}$ estimated by Falkowski et al. (1998) and Laws et al. (2000) based on CZCS and SeaWiFS data, respectively. This discrepancy may arise because (1) the approach used in this study depends on the assumed length of the productive season, and (2) the nitrate drawdown method may overestimate the new production (Koeve 2001). It is worth comparing this new production with the estimates for other polar regions. For a phytoplankton bloom with strong presence of Phaeocystis sp. observed in the Greenland Sea in 1989, Smith et al. (1991) reported a new primary production of $40 \mathrm{~g} \mathrm{C} \mathrm{m}^{-2}$ over a period of $35 \mathrm{~d}$, which corresponds to $1.1 \mathrm{~g} \mathrm{C} \mathrm{m}^{-2} \mathrm{~d}^{-1}$. For the Bransfield Strait a new daily production of $1.7 \mathrm{~g} \mathrm{C} \mathrm{m}^{-2} \mathrm{~d}^{-1}$ was reported (Karl et al. 1991), and a production of $2 \mathrm{gC} \mathrm{m}^{-2} \mathrm{~d}^{-1}$ for the Bering Strait, the most productive region in the Arctic (Walsh et al. 1989). Anderson et al. (2000) reported a new production for the Greenland Sea of $57 \mathrm{gC} \mathrm{m}^{-2} \mathrm{yr}^{-1}$, whereas the new production of iceedge phytoplankton blooms in the Southern Ocean was estimated as $50 \mathrm{gC} \mathrm{m}^{-2} \mathrm{yr}^{-1}$ (Smith \& Nelson 1990).
Both estimates are in the same order as the annual primary production of $76 \mathrm{gC} \mathrm{m}^{-2} \mathrm{yr}^{-1}$ estimated in this study for the Greenland shelf in the Irminger Sea sector. However, the estimates presented for the daily and subsequently annual new primary production for the Greenland shelf have to be considered cautiously because (1) the calculations of daily new production are based on the assumption of a $20 \mathrm{~d}$ growth period (end of winter in mid-April to begin of May), (2) nitrate removal was calculated assuming a surface winter nitrate concentration of $14 \mu \mathrm{m}$ (Glover \& Brewer 1988), (3) regenerated production was not taken into account, and (4) the populations consisted of Phaeocystis sp., which might not occur on a regular basis in this region.

\section{Interannual variability}

In the northern North Atlantic, stratification of the surface waters in spring will depend on (1) the offshore extension of freshwater and (2) the development of the thermocline, and may vary considerably from year to year. The satellite-derived surface chlorophyll a concentrations from SeaWiFS (1998 to 2001) show that a slight increase in chlorophyll a concentrations of up to 1 to $3 \mathrm{mg} \mathrm{m}^{-3}$ regularly occurs as early as April in the Irminger Sea along the Greenland shelf (Fig. 6), sug-
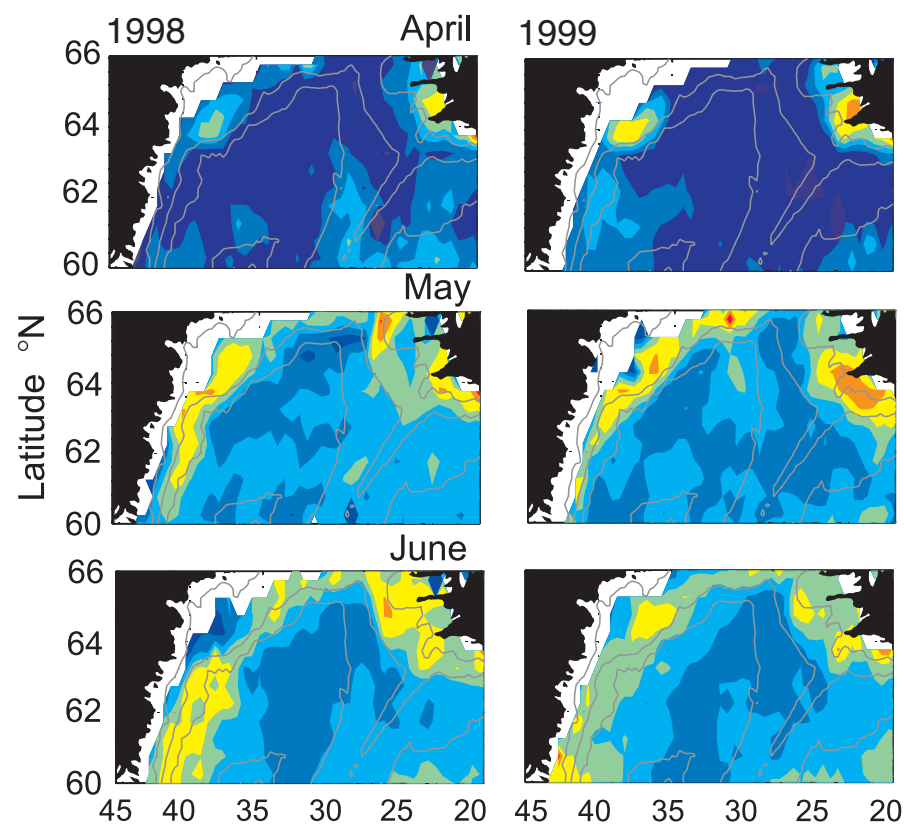
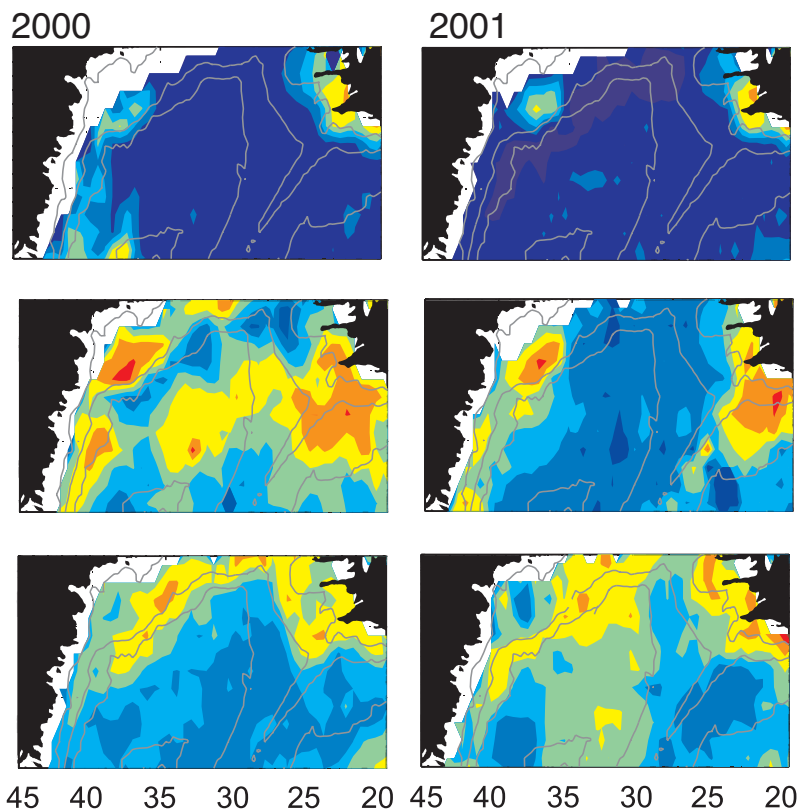

Longitude ${ }^{\circ} \mathrm{W}$

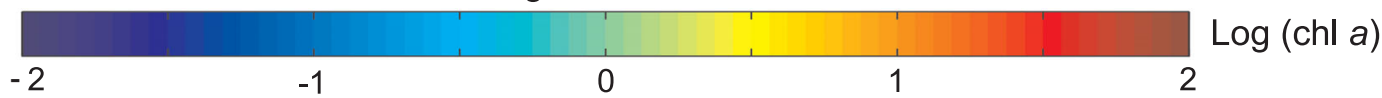

Fig. 6. Monthly mean surface chlorophyll a concentrations for April, May and June in 1998, 1999,2000 and 2001 derived from SeaWiFS (as $\log \left[\mathrm{chlorophyll} \mathrm{a]} \mathrm{in} \mathrm{mg} \mathrm{m}^{-3}\right.$ ). White areas: regions without data. Superimposed are isobaths $200,1000,2000$ and $3000 \mathrm{~m}$ 


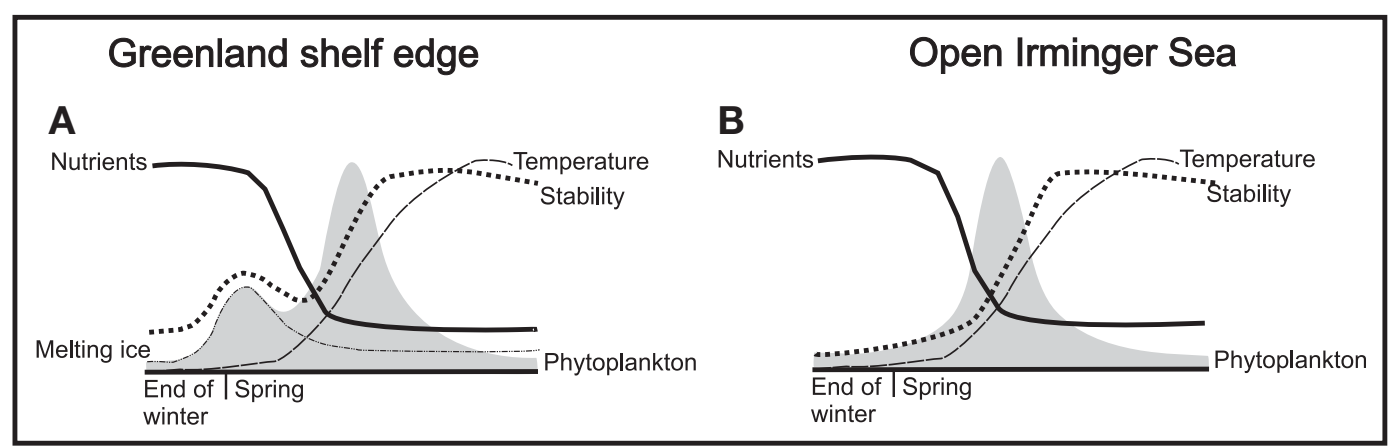

Fig. 7. Schematic presentation of spring bloom development on Greenland shelf and in open Irminger Sea. (A) On shelf, seasonal retreat of ice-cover leads to increased water stability prior to establishment of seasonal thermocline; during this time nutrient concentration declines and phytoplankton biomass increases, producing localised maximum; main phytoplankton bloom occurs when seasonal stratification is established. (B) In Irminger Sea, seasonal stratification is established later in the year because of increased solar radiation, and therefore spring bloom is delayed

gesting that such early patchy development of phytoplankton blooms in this region may not be unusual. In April and May along the Greenland shelf, the chlorophyll a concentrations derived from satellite reached up to $10 \mathrm{mg} \mathrm{m}^{-3}$ as the water column attained considerable stability due to fresh water dilution of the surface water, while in June there occurred a basin-wide development of high chlorophyll a concentrations due to formation of the seasonal thermocline. In contrast, in April and May (1998 to 2001), the open Irminger Sea was always characterised by chlorophyll a concentrations below $1 \mathrm{mg} \mathrm{m}^{-3}$ (Fig. 6). Thus, the shallow nearshore waters become stratified considerably earlier than the deeper more haline region in the central part of the Irminger Sea. On the shelf, the seasonal increase in temperature does not contribute to the onset of the vernal blooming. Temperature starts to contribute to the stratification later, followed by a basin-wide increase in chlorophyll a concentrations, as indicated by remote-sensing (Fig. 6).

\section{CONCLUSION}

In the melting-ice zone of the Greenland shelf in the Irminger Sea, water-column stratification enhances phytoplankton development due to salinity and temperature gradients. The strong spatial coherence between the zone of increased water stability and the standing stock of phytoplankton is evidence of the close relationship between phytoplankton abundance and vertical stratification (Sverdrup 1953). At the same time, the decrease in stratification outside the meltwater input in the open Irminger Sea allowed for more active mixing in the water column, resulting in a net transport of phytoplankton to greater depth and spatial limitation of the bloom's surface manifestation or clearly retarded development (Fig. 7). The hydrography and the nutrient distribution as well as the chlorophyll $a$ concentrations and phytoplankton species indicate that the conditions for the onset of the spring bloom and the development stages of the bloom are quite variable on the Greenland shelf in the Irminger Sea, and may considerably vary on the sub-mesoscale. Different adaptations to the physical regime together with grazing pressure on the phytoplankton community show variability at the same spatial scale and lead to the observed differences in the vertical chlorophyll a distribution. The different water bodies, their transport across the transect, together with the resulting variability in the timing of the spring bloom give rise to a rather patchy distribution of phytoplankton in this region, where contrasting bloom stages lie next to each other.

Acknowledgements. The authors thank the ship's crew, Dr. R. Pollard and Dr. K. Richards and the scientists involved in the Marine Productivity cruise. The Marine Productivity thematic programme was funded by the Natural Environment Research Council (NERC, UK) and is a contribution to UK Globec. SeaWiFS data were provided by NASA GFSFC DAAC at http://daac.gsfc.nasa.gov/data/dataset/SEAWIFS/. We thank the 3 anonymous reviewers for their comments and their help in clarifying and improving the manuscript.

\section{LITERATURE CITED}

Allen KR (1971) Relation between production and biomass. J Fish Res Board Can 28:1537-1581

Anderson LG, Drange H, Chierici M, Fransson A, Johannessen T, Skjelvan I, Rey F (2000) Annual carbon fluxes in the upper Greenland Sea based on measurements and box model approach. Tellus 52:1013-1024

Bacon S, Reverdin G, Rigor I G, Snaith H M (2002) A freshwater jet on the east Greenland Shelf. J Geophys Res C 107: 10.1029/2001JC000935

Benke AC (1984) Secondary production. In: Resh VH, Rosenber DM (eds) The ecology of aquatic insects. Praeger Publishing, New York, p 289-322 
Bienfang PK, Syper J, Lows E (1983) Sinking rate and pigment responses to ligh limitation of marine diatoms: implications to dynamics of chlorophyll maximum layers. Oceanol Acta 6:55-62

Campbell JW, Aarup T (1992) New production in the North Atlantic derived from seasonal patterns of surface chlorophyll. Deep-Sea Res 39:1669-1694

Castelani C (2002) Oithona and Calanus nauplii studies. In: Richards K and Marine Productivity researchers (eds) Marine productivity cruise report, Vol 2. Natural Environmental Research Council, Swindon, p 40-44

Cloern JE (1996) Phytoplankton bloom dynamics in coastal ecosystems: a review with some general lessons from sustained investigation of San Francisco Bay, California. Rev Geophys 34:127-168

Cushing DH (1989) A difference in structure between ecosystems in strongly stratified waters and in those that are only weekly stratified. J Plankton Res 11:1-13

Deuser WG, Ross EH (1980) Seasonal change in the flux of organic carbon to the deep Sargasso Sea. Nature 283: 364-365

Dickey TD (1988) Recent advances and future directions in multi-disciplinary in situ oceanographic measurements system. In: Rothschild BJ (ed) Toward a theory on biological-physical interactions in the world ocean. Kluwer Academic Press, Dordrecht, p 555-598

Eppley RW, Read F, Strickland J (1970) Ecology of the plankton of La Jolla, California, in the period April through September 1967. Bull Scripps Inst Oceanogr Univ Calif 17: $33-42$

Falkowski PG, Barber RT, Smetacek V (1998) Biogeochemical controls and feedbacks on ocean primary production. Science 281(5374):200-206

Falkowski PG, Scholes RJ, Boyle E, Canadell J and 13 others (2000) The global carbon cycle: a test of our knowledge of earth as a system. Science 290:291-296

Fisher TR, Harding LW, Stanley DW, Ward LG (1988) Phytoplankton, nutrients and turbidity in the Chesapeake Deleware and Hudson estuaries. Estuar Coast Shelf Sci 27: 61-93

Garçon V, Oschlies A, Doney S, McGillicuddy D, Waniek J (2001) The role of mesoscale variability on plankton dynamics in the North Atlantic. Deep-Sea Res II 48: $2199-2226$

Glover DM, Brewer PG (1988) Estimates of wintertime mixed layer nutrient concentrations in the North Atlantic. DeepSea Res 35:1525-1546

Harrison W, Head E, Horne E, Irwin B, Li W, Longhurst A, Paranjape M, Platt T (1993) The western North Atlantic bloom experiment. Deep-Sea Res 40:279-305

Heinrich AK (1962) The life histories of plankton animals and seasonal cycles of plankton communities in the ocean. J Cons Perm Int Explor Mer 27:15-24

Henson SA, Sanders R, Allen JT, Robinson IS, Brown L (2003) Seasonal constraints on the estimation of new production from space using temperature-nitrate relationships. Geophys Res Lett 30:doi:10.1029/2003/GRL17982

Holligan PM, Harris RP, Newell RC, Harbour DC, Read RN, Lidley E, Lucas MI, Tranter P, Weekly CM (1984) Vertical distribution and partitioning of organic carbon in mixed, frontal and stratified waters of the English Channel. Mar Ecol Prog Ser 14:111-127

Honjo S (1996) Fluxes of particles to the interior of the open oceans. SCOPE 57:91-145

Huisman J, van Oostveen P, Weissing FJ (1999) Species dynamics in phytoplankton blooms: incomplete mixing and competition for light. Am Nat 154:46-68
Hutchings L, Pitcher GC, Probyn TA, Bailey GW (1995) The chemical and biological consequences of coastal upwelling. In: Summerhayes CP, Emeis $\mathrm{KC}$, Angel MV, Smith RL, Zeitzschel B (eds) Upwelling in the ocean: modern processes and ancient records. J Wiley \& Sons, Chichester, p 65-83

Irigoien X, Head R, Klenke U, Meyer-Harms B, Harbour D, Niehoff B, Hirche HJ, Harris R (1998) A high frequency time series at weathership $M$, Norwegian Sea, during the 1997 spring bloom: feeding of adult female Calanus finmarchicus. Mar Ecol Prog Ser 172:127-137

Irigoien $\mathrm{X}$, Head RN, Harris RP, Cummings D, Harbour D, Meyer-Harms B (2000) Feeding selectivity and egg production of Calanus helgolandicus in the English Channel. Limnol Oceanogr 45:44-54

Irigoien $\mathrm{H}$, Titelman $\mathrm{J}$, Harris RP, Harbour D, Castellani C (2003) Feeding of Calanus finmarchicus nauplii in the Irminger Sea. Mar Ecol Prog Ser 262:193-200

Jeffrey SW, Humphrey GF (1975) New spectrophotometric equation for determining chlorophyll a, b, c1 and c2. Biochem Physiol Pflanz 167:194-204

Karl DM, Tilbrook BD, Tien G (1991) Seasonal coupling of organic matter production and particle flux in the western Bransfield Strait, Antarctica. Deep-Sea Res 38A: 1097-1126

Kirkwood DC (1995) The SanPlus segmented flow autoanalyser and its applications. Skcalar Analytical BV Publications, Breda

Koeve W (2001) Wintertime nutrients in the North Atlanticnew approaches and implications for new production estimates. Mar Chem 74:245-260

Kovala PE, Larrance JD (1996) Comparison of phytoplankton cell numbers, cell volume, cell surface and plasma volume, per metre, from microscopic counts. Spec Rep No. 36, Univ Washington, Seattle

Lancelot C, Mathot S, Veth C, de Baar H (1993) Factors controlling phytoplankton ice-edge blooms in the marginal ice-zone of the northwestern Weddell Sea during sea ice retreat 1988: field observations and mathematical modelling. Polar Biol 13:377-387

Laws EA, Falkowski PG, Smith WO Jr, Ducklow H, McCarthy JJ (2000) Temperature effects on export production in the open ocean. Global Biogeochem Cycles 14:1231-1246

Le Fevre J (1986) Aspects of biology of frontal systems. In: Blaxter JHS, Southward AJ (eds) Advances in marine biology, Vol 23. Academic Press, London, p 1-385

Margalef R (1978) Life-forms of phytoplankton as survival alternatives in an unstable environment. Oceanol Acta 1: 493-509

Martin AP (2003) Phytoplankton patchiness: the role of lateral stirring and mixing. Prog Oceanogr 57:125-174

Moore JK, Abbott MR (2002) Surface chlorophyll concentrations in relation to the Antarctic Polar Front: seasonal and spatial patterns from satellite observations. J Mar Syst 37: 69-86

Peinert R (1986) Production, grazing and sedimentation in the Norwegian Coastal Current. In: Skreslet S (ed) The role of freshwater outflow in coastal marine ecosystems. SpringerVerlag, Berlin, p 361-375

Peperzak L, Colijn F, Gieskes WWC, Peeters JCH (1998) Development of the diatom-Phaeocystis spring bloom in the Dutch coastal zone of the North Sea: the silicon depletion versus the daily irradiance threshold hypothesis. J Plankton Res 20:517-537

Rat'kowa TN, Wassmann P (2002) Seasonal variation and spatial distribution of phyto- and protozooplankton in the central Barents Sea. J Mar Syst 38:47-75 
Read JF, Pollard RT, Bathmann U (2002) Physical and biological patchiness of an upper ocean transect from South Africa to the ice edge near the Greenwich Meridian. Deep-Sea Res 49:3713-3733

Redfield AC, Ketchum BH, Richard FA (1963) The influence of organisms on the composition of seawater. In: Hill MN (ed) The sea. Wiley, New York, p 26-77

Rice AL, Billet DSM, Fry J, John AWG, Lampitt RS, Mantoura RFC, Morris RJ (1986) Seasonal deposition of photodetritus to the deep-sea floor. In: Mauchline J (ed) The oceanography of the Rockall Channel. Proc R Soc Edinb Sect B 88:265-279

Richards K and Marine Productivity researchers (2002) Marine productivity cruise report, Vol 2. Natural Environment Research Council, Swindon

Sanders R, Brown L (in press) New production in the Irminger Basin during 2002. J Mar Syst

Sanders R, Jickells T (2000) Total organic nutrients in Drake Passage. Deep-Sea Res 47:997-1014

Sarmiento JL, Toggweiler JR (1984) New model for the role of the oceans in determining atmospheric $\mathrm{pCO}_{2}$. Nature 308 : $621-624$

Savidge G, Turner D, Burkill P, Watson A, Angel M, Pingree R, Leach H, Richards K (1992) The BOFS 1990 spring bloom experiment: temporal evolution and spatial variability of the hydrographic field. Prog Oceanogr 29:235-281

Serret P, Fernandez E, Anadon R, Varela M (2001) Trophic control of biogenic carbon export in Bransfield and Gerlache Straits, Antarctica. J Plankton Res 23:1345-1360

Siedler G (1998) SI-units in oceanography. Ber Inst Meereskd Kiel 101:1-19

Smetacek V, Scharek R, Nöthig E (1990) Seasonal and regional variation in the pelagial and its relationship to the life history cycle of krill. In: Kerny R, Hempel G (eds) Antarctic ecosystems: ecological change and conservation. Springer-Verlag, Berlin, p 103-114

Smith WO Jr, Nelson DM (1990) Phytoplankton growth and new production in the Weddell Sea marginal ice zone

Editorial responsibility: Otto Kinne (Editor-in-Chief), Oldendorf/Luhe, Germany in the austral spring and autumn. Limnol Oceanogr 35: 809-821

Smith WO Jr, Codispoti LA, Nelson DM, Manley T, Buskey EJ, Niebauer HJ, Cota GF (1991) Importance of Phaeocystis blooms in the high-latitude ocean carbon cycle. Nature 352:514-516

Strass VH (1992) Chlorophyll patchiness caused by mesoscale upwelling at fronts. Deep-Sea Res 39:75-96

Strass VH, Nöthig E (1996) Seasonal shifts in ice edge phytoplankton blooms in the Barents Sea related to the water column stability. Polar Biol 16:409-422

Strass VH, Woods JD (1988) Horizontal and seasonal variations of density and chlorophyll profiles between the Azores and Greenland. In: Rothschild BJ (ed) Toward a theory on biological-physical interactions in the world ocean. Kluwer Academic Press, Dordrecht, p 113-136

Sukhanova IN, Semina HJ, Ventsel MV (1999) Spatial distribution and temporal variability of phytoplankton in the Bering Sea. In: Loughlin TR, Ohtani K (eds) Dynamics of the Bering Sea. University of Alsaka, Fairbanks, AK, p 453-483

Sverdrup HU (1953) On conditions for the vernal blooming of phytoplankton. J Cons Perm Int Explor Mer 18:287-295

Thordardottir T (1986) Timing and duration of spring blooming south and southwest of Iceland. In: Skreslet S (ed) The role of freshwater outflow in coastal marine ecosystems. Springer-Verlag, Berlin, p 345-360

Tungaraza C, Rousseau V, Brion N, Gichuki J, Baeyens W, Goeyens L (2003) Contrasting nitrogen uptake by diatom and Phaeocystis-dominated phytoplankton assemblages in the North Sea. J Exp Mar Biol Ecol 292:19-41

Walsh JJ, McRoy CP, Coachman LK, Goering JJ and 17 others (1989) Carbon and nitrogen cycling within the Bering/ Chukchi Seas: source regions for organic matter effecting AOU demands of the Arctic Ocean. Prog Oceanogr 22: $277-359$

Waniek J (2003) The role of physical forcing in initiation of spring blooms in the Northeast Atlantic. J Mar Syst 39: $57-82$

Submitted: June 11, 2004; Accepted: September 28, 2004 Proofs received from author(s): February 21, 2005 